\title{
The Australian Parliament and press freedom in an international context
}

ABBSIRACII

This article reports on a study using grounded theory methodology to track the contexts in which Australian parliamentarians used the expressions 'press freedom' and 'freedom of the press' over the ten years from 1994 to 2004. It uses Parliamentary Hansard records to identify the speeches in which discussions of press freedom arose. Interestingly, the terms were used by members of the House of Representatives or Senate in just 78 speeches out of more than 180,000 over that decade. Those usages have been coded to develop a theory about the interface between press freedom and the parliament. This article reports just one aspect of the findings from the larger study - the way parliamentarians have contrasted the value of press freedom in Australia with press freedom in other countries. It is one step towards building a broader theory of press freedom in the Australian parliamentary context.

\section{MARK PEARSON and CAMILLE GALVIN \\ Bond University, Queensland}

7 HE concept of press freedom has been a hallmark of democracy, dating back to at least 1644 when the poet and philosopher John Milton

wrote his Areopagitica, a speech to the Parliament appealing for the freedom of the presses (Patrides, 1985).

English liberal ideals expounded by the likes of Milton and John Locke were adopted into the American Declaration of Independence in 1776 and into the US Constitution in 1789 and its Bill of Rights in 1791. The Bill of Rights' key media provision was found in the First Amendment to the US Constitution which enshrined freedom of the press: 
Congress shall make no law respecting an establishment of religion, or prohibiting the free exercise thereof; or abridging the freedom of speech, or of the press; or the right of the people peaceably to assemble, and to petition the government for a redress of grievances.

It was during public debate over the wording of the First Amendment and in the debates over its ratification by the States that Thomas Jefferson, probably the most quoted advocate of press freedom, wrote:

The basis of our government being the opinion of the people, the very first object should be to keep that right; and were it left to me to decide whether we should have a government without newspapers or newspapers without a government, I should not hesitate a moment to prefer the latter.-Thomas Jefferson to Edward Carrington, 1787. (Inglebart, 1987)

Thus, it is clear from the international experience that politicians in Britain and the United States were crucial to the establishment of press freedom as an important democratic principle. This article looks to the speeches of Australian parliamentarians to gauge how the expression 'press freedom' has been used over recent years.

Pearson (2004) notes the extent to which Australia's judiciary had discussed principles of press freedom and its broader cousin —an implied constitutional freedom to communicate on matters of politics_-during a series of decisions throughout the 1990s. The three phases of High Court decisions had a major impact on the interpretation of free speech in Australia, a nation without a bill of rights guaranteeing a free media and without any such formal guarantee in its constitution. The decisions were handed down in 1992, 1994 and 1997. A further decision in 2001 clarified and restated the High Court's position on free speech. The first two important decisions were Australian Capital Television Pty Ltd v. Commonwealth (1992) 177 CLR 106; and Nationwide News Pty Ltd v. Wills (1992) 177 CLR 1. The High Court found key pieces of Commonwealth legislation impinged upon citizens' rights to communicate on matters of politics and government, a right the High Court majority said was fundamental to the system of representative government and implied in the Constitution, while not explicitly stated there. Two cases in 1994 tested the extent to which this could be used by the media in defending defamation 
actions_Stephens v West Australian Newspapers Ltd (1994) 182 CLR 211 and Theophanous $v$ Herald and Weekly Times Ltd (1994) 182 CLR 104-where the High Court developed a defence to defamation premised upon the same implied constitutional guarantee of political communication. The test of this new defence came in 1997 in Lange v Australian Broadcasting Corporation (1997) 189 CLR 520, where the High Court decided unanimously to reaffirm the implied guarantee of political free speech, to extend the political qualified privilege defence, but to do away with the new defamation defence. From 2001-2003 the High Court dealt with five more media-related cases which also raised questions of press freedom. They were: Australian Broadcasting Corporation v Lenah Game Meats Pty Ltd (2001), Dow Jones \& Company Inc. v Gutnick (2002), Roberts v Bass (2002), John Fairfax Publications Pty Ltd v Rivkin (2003), and Rogers v Nationwide News Pty Ltd (2003).

If the highest judicial body in Australia was so occupied with principles of free speech and its relationship to press freedom over the decade, then what were the key forums of the legislature saying about press freedom over that same period? This article sets out to offer some preliminary insights into that question.

\section{Previous research}

There is a large body of research examining the role the media play in the political system. In Australia, Henry Mayer (1964) devoted a chapter to 'Parliament Versus Press' in his seminal work, The Press in Australia. It is a short yet compelling account of the often rocky relationship between politicians and the media to that point in Australian history. The key recent work in the field is Ian Ward's Politics of the Media (Ward, 1995), which takes a social scientist's approach to the role of the media in the Australian political system and power structure. There have been studies of the Canberra press gallery, such as those by Kingston (1999) and Simons (1999). Numerous scholars have devoted journal articles and books to special aspects of the junction between the media and politics, as detailed in the section on 'Politics' in Dobinson's (2001-2002) Australian Journalism Research Index. None have dealt in detail with the specific issue of press freedom as a topic of discussion in Parliament.

Internationally, there have been countless works in the field of media and politics, but again few have homed in on the press freedom issue. Van Belle 
(2000) takes up the issue of press freedom and sets out to assess its role in international relations. Van Belle tries to gauge the effect of a free press on world disputes and produces empirical data to demonstrate its role.

Pitts (2000) seems to be the only international scholar to take up the issue of parliamentarians' attitudes to the media. He did so by surveying 58 members of the Zambian Parliament on their attitudes to bias and accuracy in news reporting, citizen involvement in democracy, politicians' relationship with the media, and their sources of information. More than half of the Zambian politicians (57.1 percent) felt press freedom should be increased and Pitts explained this attitude in the context of 'a society which has sought to control information and ideas'. No similar studies have been reported elsewhere.

One of the authors of this article has already conducted some preliminary studies of the relationship between Australia's High Court and the media, with a special emphasis on that court's view of the modern media and its role in society, particularly with regard to notions of press freedom (Pearson, 2004). That pilot study found there had been an identifiable shift in the High Court's attitude to media, journalism and free press principles, evident in five recent judgments by two of the High Court justices. It was encapsulated in the term 'The Modern Media' used by both Justices Callinan and Kirby in their judgments in Australian Broadcasting Corporation v Lenah Game Meats Pty Ltd (2001). Its symptoms were the explicit questioning of previously established values and principles, including the media's Fourth Estate role, the special position of public trust it holds, its special circumstances of production, and its 'benefit of the doubt' in the realm of public interest issues such as court reporting defences and prior restraint.

Given that the judiciary has such views on the media and press freedom, it is relevant to question the attitudes of the other important lawmaking body - the legislature - to those very issues. This small study aims to make some initial headway into that territory by examining the contexts in which parliamentarians have used the expressions 'press freedom' or 'freedom of the press' in their speeches over the past decade.

Such a study has not been undertaken previously. Others have explored the relationship between the media and parliamentarians, but have focussed on other questions. This study has a very simple question in mind: In what contexts have Australian federal politicians mentioned press freedom in their speeches and what does that tell us about their attitudes to this principle? 
This article reports just one aspect of the findings from the study-the way parliamentarians have contrasted the value of press freedom in Australia with press freedom in other countries.

\section{Methodology}

A full text search of Hansard for the Australian Senate and House of Representatives was conducted using the Parlinfo web interface for the ten year period from 1 September 1994 to 1 September 2004. ${ }^{1}$ The expression 'freedom of the press' arose in a total of 71 speeches over the period and the expression 'press freedom' occurred in eight speeches, one of which was a repeat of one of the first 71 hits, leaving a total of 78 speeches in which either of the expressions was mentioned. (For the purposes of this article, the phrase 'press freedom' is used to refer to both 'press freedom' and 'freedom of the press'.)

These results were subject to a basic count on four criteria: party affiliation of speaker, number of mentions per year, number of mentions per house of Parliament and sentiment towards press freedom expressed by the parliamentarian. The sentiment of the speaker was determined by looking at the context of the expression and a judgment was made as to whether the politician seemed to be placing a positive, negative or neutral value on the principle of press freedom.

All 78 speeches were then input into the qualitative data processing software N6 and coded, using a variation of Glaser and Strauss's grounded theory approach, first expounded by Glaser and Strauss (Glaser \& Strauss 1967; Strauss \& Corbin 1987) and later refined by Strauss and Corbin (1987; Strauss \& Corbin 1990; Glaser 1992). The grounded theory process involves extended analysis over a range of stages. Its founders called it the 'constant comparison method of qualitative analysis' (Glaser and Strauss, 1967, p. 106). Specific techniques of analysis include the techniques of open coding, axial coding and selective coding as well as the display technique of the conditional matrix. After such an intensive coding and analysis process, the researcher should be able to articulate a key theory which emerges from the data, some new insight which has been achieved through this empirical procedure.

It is important to note that only the immediate context or phraseology surrounding the expressions 'press freedom' and 'freedom of the press' were subject to the coding process. Some of the documents were very large speeches 
which covered extended terrain, and it was considered inappropriate to extend the coding too far from the terms themselves. Nevertheless, the broader context of the speech was of course noted and forms part of the discussion below.

Finally, after the selective coding process was complete, a theory of Australian federal parliamentarians' usage of the terms 'press freedom' and 'freedom of the press' was developed, illustrated in a conditional matrix form.

\section{Quantitative results}

The first figure worthy of comment was that in the course of a ten year period, during which thousands of speeches were made in the two houses of Federal Parliament, the expressions 'press freedom' or 'freedom of the press' were uttered in only 78 speeches. (The terms have so little to distinguish them from each other that we took them to be used interchangeably.) A count revealed there were 18,943 speeches in the House of Representatives and the Senate during just one calendar year-2003.

If this was reflected in other years, the total number of speeches and questions over the ten years would be something around 190,000, of which just 78 used these two important democratic expressions. To give this further context, a similar count would need to be conducted on comparable parliaments in other countries, such as the US Senate and House of Representatives and the British House of Lords and House of Commons. That would take a much larger study. To add another point of comparison, a ten-year search was also conducted on the terms 'fair trial' (114 speeches) and 'privacy' (200 speeches).

A very basic breakdown was conducted on the 78 speeches in which the terms 'press freedom' or 'freedom of the press' was used, represented in Tables 1, 2, 3 and 4 .

Table 1 shows the party affiliation of speakers referring to press freedom over the ten-year period. The breakdown does not hold any great surprises

\begin{tabular}{|l|l|}
\hline \multicolumn{2}{|l|}{ Table 1: Party affilliation of speakers referring to press freedom } \\
\hline Party & Number of speakers \\
\hline Liberal Party & 29 \\
\hline Australian Labour Party & 28 \\
\hline National Party & 5 \\
\hline Australian Democrats & 9 \\
\hline Greens & 7 \\
\hline
\end{tabular}




\begin{tabular}{|l|l|}
\hline \multicolumn{2}{|l|}{ Table 2: Speeches mentioning press freedom by year } \\
\hline Year & $\begin{array}{l}\text { Number of speeches mentioning } \\
\text { 'press freedom' or 'freedom of the } \\
\text { press' }\end{array}$ \\
\hline 2004 (to 1/9) & 7 \\
\hline 2003 & 23 \\
\hline 2002 & 14 \\
\hline 2001 & 5 \\
\hline 2000 & 8 \\
\hline 1999 & 3 \\
\hline 1998 & 4 \\
\hline 1997 & 5 \\
\hline 1996 & 3 \\
\hline 1995 & 5 \\
\hline 1994 (from 1/9) & 1 \\
\hline
\end{tabular}

and generally reflects the party representation over the decade. It is noteworthy that, despite the low number of mentions overall, it appears to be a bipartisan phenomenon, at least in its mention. A more refined analysis might indicate whether there were differences in the attitudes to press freedom among parliamentarians of different party affiliations. For example, what if all 28 mentions of press freedom by ALP politicians were negative ones? That would make the above table illusory if the other parties' mentions were all in a positive context.

It is interesting that most references of press freedom were made over the final three years of the study, many of which were during discussion of proposals to ease cross-media and foreign ownership restrictions and to curb reporters' rights under anti-terrorism legislation. While it is not surprising that such an issue arose during such debates, it is noteworthy that so few mentions were made of press freedom during the very period (1994 to 2001) that the High Court was actively discussing media powers and press freedom, as noted by Pearson (2004b). That said, it could be that parliamentarians see media freedom as such a fundamental principle that they take it for granted and feel they do not need to articulate it. 
Table 3: Press freedom mentions by House of Parliament

\begin{tabular}{|l|l|}
\hline Senate & 34 \\
\hline House of Representatives & 44 \\
\hline
\end{tabular}

Press freedom was mentioned slightly more often during House of Representatives debate than it was during speeches and questions in the Senate (Table 3). However, there is no great significance attached to this difference.

As explained in the methodology, the sentiment was determined by looking at the immediate context in which the expression was used and a judgment was made as to whether the politician seemed to be placing a positive, negative or neutral value on the principle of press freedom (Table 4). This was a somewhat complex process, in that sometimes the words used to discuss press freedom seemed to value it as a principle, yet the speech itself was suggesting some limitation on press freedom or some preference for other liberties over press freedom. For example, on 8 November 2000, Labor Senator Robert McClelland spoke against media exemptions from a Privacy Amendment Bill, but was at pains to emphasise the importance of press freedom to democracy (08-11-00-1236). That reference was counted as a positive sentiment, even though the thrust of his comments were detrimental to media freedoms.

Given there were so few outright negative comments about press freedom, and given that several speeches spoke in favour of press freedom while recommending limitations to it, it seems politicians are keen to at least pay lip service to the importance of the principle. There may be several explanations for this, which can only be hypothesised here, such as politicians' reluctance to alienate powerful media interests and individual journalist 'mates', the occupational tendency of politicians to try to keep everyone happy, and the need to at least talk the talk expected of politicians in a Western democratic society. This is explored further in the qualitative analysis.

\begin{tabular}{|l|c|}
\hline \multicolumn{2}{|l|}{ Table 4: Parliaments' sentiments on press freedom } \\
\hline Positive sentiment & 54 \\
\hline Neutral & 21 \\
\hline Negative sentiment & 4 \\
\hline
\end{tabular}

Note: This totals 79 , rather than 78 because one speech contained the use of the expression 'press freedom' in two different contexts.

146 PACIFIC JOURNALISM REVIEW 13 (2) 2007 


\section{Towards a theory of the Parliament and press freedom}

Coding is, of course, a very subjective process. Different individuals will undoubtedly read different meanings into the contexts in which a phrase has been uttered. That said, the two coders undertaking this project agreed that the following categories of mention of press freedom emerged from the data:

- Threats to press freedom

- Rights and responsibilities of the media

- International comparisons

- Importance of press freedom to democracy

- Press freedom and media ownership

- Press freedom vis a vis other freedoms

- Proposed measures with regard to press freedom

These categories need to be further refined as the coding and analysis process proceeds, but for the purposes of this article we have taken just one category-international comparisons - to demonstrate the data analysis and theorybuilding process.

\section{International comparisons}

Australian parliamentarians used the expressions 'freedom of the press' or 'press freedom' in a range of contexts when comparing and contrasting such freedoms in Australia with those in other countries. These contexts have been categorised into three themes, which include:

- Australia as a follower of other countries' examples on press freedom, particularly the USA.

- Australia as a champion of press freedom as a democratic value, compared with other countries.

- Parliamentarians as critics of media's excesses in the name of press freedom in other countries.

\section{Australia as a follower of other countries' examples on press freedom,} particularly the USA

One type of invocation of the expression 'press freedom' was when Australian politicians pointed to other countries as leading lights in freedom of the press, from which Australia should take an example. Several parliamentarians used the term 'press freedom' when referring to the United States as setting the benchmark for press freedom in modern democratic societies 
with its First Amendment to its Constitution guaranteeing freedom of the press. National Party member Paul Neville (01-12-03-557, 15-10-02-500), when speaking against the concentration of media ownership, expressed his 'reluctance to meddle with the principle of freedom of the press', and twice quoted former US President Thomas Jefferson's famous words to John Jay in 1786: '... our liberty, which cannot be guarded but by the freedom of the press, nor that be limited without danger of losing it.'

In 2003, then Minister for Communications Senator Richard Alston spoke out against a proposal by another Senator that the broadcasting regulator have greater powers:

In America they would say that this is really scary stuff. What you are proposing here would not only be fundamentally in opposition to the First Amendment, which guarantees freedom of the press, but is George Orwell stuff. (25-06-03-1012)

In a discussion on internet regulation, Labor member Martyn Evans even went so far as to suggest that the US First Amendment protection would set the benchmark for the new technology:

Because the United States offers so much internet content and so many resources in this regard, because the United States has that First Amendment freedom, naturally that will become the prevailing global standard, no matter how much we might try to pretend otherwise. (21-06-99-1005)

In short, the United States was put on a pedestal as the bastion of press freedom, something to which Australia should aspire.

2. Australia as a champion of press freedom as a democratic value, compared with other countries

Conversely, at times Australia was portrayed as the exemplar of press freedom, with that value portrayed as a foundation stone of democracy. In a number of speeches, the parliamentarians spoke against restrictions on press freedom in other countries, including China, Vietnam, Iran, Iraq, Indonesia and Burma. In this context they were portraying Australia as a leader or champion of freedom of the press as a core democratic value. 
In 1995, Liberal member John Bradford described Vietnam as 'a completely totalitarian state in almost every sense of the word', using the lack of free speech and a free press as evidence (28-08-95 142). In the same year Greens Western Australia Senator Christabel Chamarette used a speech about academic freedom to mention the Indonesian government's closure of three magazines and to bemoan that country's lack of press freedom (31-05-95-657).

In the transition to Chinese rule in Hong Kong, former National Party leader Ian Sinclair was at pains to impress upon China the important role of a free press in a democratic society, as exemplified by Australia. He described it as a 'benchmark' criterion:

The concern that we have lies in a number of criteria which I call the benchmarks. One is the freedom of the press. The Fourth Estate is absolutely vital to society. There has to be a capacity for the media to comment without fear or favour. That does not mean that we all agree with the media. Goodness only knows, in this place I think we have more vociferous critics of the media than anywhere else in Australia. The media plays a vital role in a free society, and the people of China should not feel apprehensive about having a free press in Hong Kong. It is going to be very important that the freedom of the press is preserved. (14-10-96-108).

Sinclair's words were particularly important because they invoked the Jeffersonian approach to the media along the lines that that 'we might criticise them, but we have to have them'.

In the lead-up to the Coalition forces' invasion of Iraq in March 2003, the reference to press freedom was used by parliamentarians from both sides of politics when referring to that country's record of intimidation of the media. Liberal Party member Patrick Farmer cited a Human Rights International Alliance report from June 2001 which said more than 500 journalists and intellectuals had been killed in the previous decade (12-02-03-558). Labor Senator Peter Cook ranked freedom of the press with the separation of powers as fundamental democratic structures that were lacking in Iraq as it faced a new system of government (20-03-03-1150). Australia's democratic toleration of a free and critical media was positioned as the example for Iraq to follow.

Whereas the above examples show politicians criticising the lack of press 
freedom in other countries, in 2002 Liberal MP Alan Cadman suggested it was a factor in foreigners' selection of Australia as a migration destination and was retained by migrants after arrival as a core value. He said:

\begin{abstract}
There is a sense of nationalism and regard for this country that is not engendered by any false jingoism or false patriotism; it is something that people genuinely feel. They understand the qualities of Australia compared with other countries. They understand that we have a long and well-tested democracy. They understand that we have freedom of the press and a court system that is equal to any in the world. They understand that the United Nations rates Australia as one of the top two or three countries as far as personal freedoms are concerned. People who come to be a part of this nation quickly state their value for it. (11-03-02-558)
\end{abstract}

In summary, the usage of press freedom to position Australia as an exemplar to other countries took on two forms, with the main one being the use of our system as a lesson to less democratic societies and another being the positioning of press freedom as a core value held dear to migrants who have chosen to live here.

3. Australia as a critic of media's excesses in the name of press freedom in other countries, particularly Britain

While championing the principle of press freedom, there was also some mention of the media's abuse of their press freedom privileges in other countries. ALP member, Michael Danby in a Grievance Debate in the House of Representatives in 2003, devoted a whole speech to his views on declining journalism standards. He used both US and British examples, quoting from an article in the British Guardian newspaper in which journalist Polly Toynbee 'described what she called the "prevailing style, habit and mindset" of much British journalism. The rule, she said, was: Get the politicians, catch the government lying, denigrate, mock, kill. Never mind the substance of a policy - that's boring and time-consuming' (15-09-03-515p). Later in the same speech, Danby said: 'It would be a great tragedy if the ABC and SBS and our quality newspapers here in Australia followed the BBC and the London tabloids down the path of soft news and attack journalism.' 
The politician is positioning Australia as a country with press freedom which has not yet nurtured the excesses of unbridled media elsewhere, and warns of the dangers in letting this happen.

After the death of Princess Diana in 1997, Senator Bob Brown from the Australian Greens expressed concern about the 'harassment of the Princess by the global press' and about the conflict between press freedom and privacy. He suggested that 'the government review moves in other parts of the world in order to come to a better judgment as to where the line does lay between personal privacy and freedom of the press' (02-09-97-qwn). Again, the Senator is suggesting press freedom has run out of control in some other places, notably among the British tabloid paparazzi, and that perhaps some better form of regulation may be in order.

\section{Conclusion}

The number and variety of countries mentioned by parliamentarians in the context of press freedom indicates that, in the rare times it actually pierces their consciousness, they see press freedom as an international issue and one that Australia has the right to pronounce upon with some authority, although not apparently as much authority as the US whose First Amendment is still seen as the benchmark of press freedom. There is more reason today that discussion of press freedom be considered in an international context, since modern communication technologies including the internet and international security issues have made the discussion of press freedom in a purely domestic context less relevant.

Australian parliamentarians are happy to present Australian press freedom as a beacon to less democratic countries. However, this may be a little presumptuous since it was ranked only 41st in the Reporters Without Borders (RSF) annual index of press freedom (Pacific Media Watch, 2004). Australia was ranked behind some former Eastern bloc nations in the index, including Hungary (28), Czech Republic (19) and Poland (32), as a result of criticism from the watchdog about its policies restricting press access to refugees.

That said, Australia's stand on Iraq and its participation in the Coalition of the Willing in the Iraq War in 2003 might be interpreted by some as meaning that championing basic democratic values such as press freedom may have been taken a step beyond rhetoric. While it is interesting to discuss these perspectives on the international comparisons and contexts of press freedom 
in the words of Australian parliamentarians, it seems much more significant that they have only been motivated to utter the words in 78 speeches over ten years.

Further exploration of that statistic, along with the analysis of the other categories of coding, may lead to the development of a broader theory on the Australian Parliament and press freedom.

\section{Cases cited}

Australian Capital Television Pty Ltd v Commonwealth (1992) 177 CLR 106.

Nationwide News Pty Ltd v Wills (1992) 177 CLR 1.

Stephens v West Australian Newspapers Ltd (1994) 182 CLR 211.

Theophanous $v$ Herald and Weekly Times Ltd (1994) 182 CLR 104.

Lange v Australian Broadcasting Corporation (1997) 189 CLR 520.

Australian Broadcasting Corporation v Lenah Game Meats Pty Ltd [2001] HCA 63

(15 November 2001). Retrieved on 14 October 2003 from: www.austlii.edu.au

Dow Jones \& Company Inc. v Gutnick [2002] HCA 56 (10 December 2002). Retrieved on 13 October 2003 from: www.austlii.edu.au

Roberts v Bass [2002] HCA 57 (12 December 2002). Retrieved on 14 October 2003 from: www.austlii.edu.au

John Fairfax Publications Pty Ltd v Rivkin [2003] HCA 50 (10 September 2003). Retrieved on 14 October 2003 from: www.austlii.edu.au

Rogers v Nationwide News Pty Ltd [2003] HCA 52 (11 September 2003). Retrieved on 14 October 2003 from: www.austlii.edu.au

\section{Note}

1. Speeches are referenced within the text by date and time of delivery. For example, West Australian Greens Senator Christabel Chamarette is cited as '31-05-95-657', indicating she started speaking at $6.57 \mathrm{pm}$ on May 31, 1995. Speeches can be accessed at the Parlinfo Web site at http://parlinfoweb.aph.gov.au/piweb/. The term 'speeches' includes all items logged to the Parlinfo web database which includes actual speeches of members to either House and short items including questions on notice, questions without notice, questions of the Speaker, notices, and procedural text such as the reading of the titles of Bills.

\section{References}

Dobinson, G. (2001-2002). Australian journalism research index 1992-2002. Australian Studies in Journalism, 10-11(12): pp. 268-356.

Glaser, B. G. (1992). Basics of grounded theory analysis. Mill Valley, CA: Sociology Press.

Glaser, B. G. and A. L. Strauss (1967). The discovery of grounded theory: strategies for qualitative research. New York: Aldine de Gruyter. 
Inglebart, L. E. (1987). Press freedoms. a descriptive calendar of concepts, interpretations, events, and court actions, from $4000 B C$ to the present. New York: Greenwood Press.

Kingston, M. (1999). Inside the Canberra press gallery. Sydney: UNSW Press.

Mayer, H. (1964). The press in Australia. Melbourne: Lansdowne Press.

Pacific Media Watch (2004, October 27) 4548 REGION: NZ rates ninth in RSF media freedom listing. Pacific Media Watch Online. Retrieved on 14 November 2004 from: www.pmw.c2o.org

Patrides, C. A. (Ed.) (1985). John Milton: selected prose. Columbia: University of Missouri Press.

Pearson, M. (2004). The journalist's guide to media law._Dealing with legal and ethical issues. Sydney: Allen \& Unwin.

Pearson, M. (2004). Press freedom and the High Court in the Callinan era: rethinking the rhetoric. Pacific Journalism Review, 10(1): pp. 123-138.

Pitts, G. (2000). Democracy and press freedom in Zambia: attitudes of members of Parliament toward media and media regulation. Communication Law and Policy 5(2): pp. 1081-1680.

Simons, M. (1999). Fit to print: inside the Canberra press gallery. Sydney: UNSW Press.

Strauss, A. and J. Corbin (1987). Qualitative analysis for social scientists. Cambridge: Cambridge University Press.

Strauss, A. and J. Corbin (1990). Basics of qualitative research: grounded theory procedures and techniques. Newbury Park: Sage.

Van Belle, D. A. (2000). Press freedom and global politics. Westport, CT: Praeger.

Ward, I. (1995). Politics of the media. South Melbourne: Macmillan Education Australia.

Mark Pearson is professor of journalism and Camille Galvin is a research assistant at Bond University. The researchers wish to acknowledge funding for this study provided by the university's Faculty of Humanities and Social Sciences. An earlier version of this article was presented to the annual conference of the Journalism Education Association, Suva, Fiji, 8December 2004. mpearson@bond.edu.au 